\title{
Combating wildlife crime
}

\author{
Linzi Wilson-Wilde
}

Published online: 22 July 2010

(C) Springer Science+Business Media, LLC 2010

It is with great pleasure that I introduce this special edition dedicated to wildlife crime. Wildlife crime is an important area of law enforcement that I have a strong commitment to. It involves the illegal trade in animals, plants and their derivatives and can result in the depletion of natural resources, invasion of pest species and the transmission of diseases. For the first time an international journal has dedicated an entire edition to the issue of wildlife crime, bringing together submissions from numerous global experts regarding their work in this area. The aim of this initiative is to generate attention to this significant criminal activity.

The current global situation is summarized and discussed in the commentary by Wilson-Wilde [1]. In a positive move, international action is becoming more coordinated and an overview of the 2009 INTERPOL Wildlife Crime Group meeting in Brazil is presented in the commentary by Neme [2].

At the international level there are 175 signatories to the Convention on International Trade in Endangered Species of Wild Fauna and Flora (CITES) [3]. CITES provides a system of control to inhibit the exploitation of animals and plants and prevent trade from threatening the extinction of endangered species. Fauna and flora are listed on one of the three Appendices of CITES. Appendix I lists species where international trade is prohibited (exceptions are made for non-commercial purposes, such as scientific research), Appendix II lists species where international trade is regulated in circumstances where the trade does not endanger

L. Wilson-Wilde $(\bowtie)$

ANZPAA National Institute of Forensic Science,

Melbourne, VIC, Australia

e-mail: linzi.wilson-wilde.nifs@anzpaa.org.au the survival of the species and Appendix III lists species where international trade is regulated at the request of a particular country (for example Uruguay has listed the eleven banded armadillo). Paramount to the enforcement of CITES and the subsequent prosecution of offenders is the ability to identify the species in question. Alacs et al. [4] provide an excellent review of genetic DNA analysis methods used in the forensic investigation of wildlife crime, covering various available techniques that can be applied and techniques that have potential for future application. Tobe and Linacre take this a step further investigating the use of DNA techniques in mixed samples from more than one species [5] and Spencer et al. [6] extend DNA techniques to the analysis of historical and degraded samples with much success.

Offenders of wildlife crime can be categorized into three main groups; minor offenders, organized illegal trading and serious major criminal activity [7]. Minor offenders generally relate to abuses against conditions in permits and are more opportunistic types of crime. These offenders are usually tracked through inadequate record keeping and generally involve exchanges between wildlife collectors. Organized illegal trading moves into the realms of deliberate clandestine poaching with intent to make gain and meet the needs of the market. It requires planning and can threaten wildlife, with no consideration of their habitat, for monetary gain in selling specimens on the black market. Serious major criminal activity differs from the latter in that it is highly organized involving major criminal groups who are professional, financially backed and specifically market products. These offenders may also be involved in major fraud and drug shipping [7]. Therefore combating criminal activity requires a well-equipped forensic facility to provide cutting edge technology, maximizing evidentiary outputs. Setting up such a laboratory is not easy and 
Ogden clearly highlights some of the issues and provides an insight into how this might be achieved [8].

It is difficult to ascertain specifically what drives demand in particular wildlife trade; however it is thought that a number of factors such as fashion, rarity of the species, trends in alternative remedies and medicine and criminal elements each play a part. Fashion can have a major impact and is highly variable. Particularly endangered species cost more and can therefore be in higher demand by collectors due to higher profits compared to the risks and penalties incurred. Simply placing a species on the CITES list, Appendix I can make a species more appealing. Yates et al. [9] look at the identification of hairs from elephant and giraffe used in traditional style jewelry (presumably bound for the tourist trade) using light microscopy.

A number of very interesting case studies are included in this edition to highlight the impact wildlife crime has on the animals involved and the type of forensic analysis that must be undertaken to assist the investigation. Byard et al. [10] present a case study on unusual upper aerodigestive tract obstructions in wild dolphins causing death. Byard et al. [11] also discuss a case study on unexpected deaths in captive fur seals and Carapetis et al. [12] present a case illustrating the consequences of ingesting foreign material by seabirds. In the article by Johnson two interesting case studies are discussed regarding the illegal importation of live bird eggs and the illegal possession of shark fins [13].

Wildlife crime also includes offences involving domesticated species, such as animal cruelty cases and where an animal may be used to link an individual to the commission of an offence (for example dog hairs on a suspect). El-Sayed et al. [14] investigate the use of DNA analysis in domesticated species and Clarke and Vandenberg look at the application of canine DNA profiling in forensic casework [15]. Wilson-Wilde et al. [16] look at species identification in the context of a laboratory conducting standard DNA analysis and implications and recommendations for implementing a species identification method. Two book reviews are also included in this special edition, Forensic Science in Wildlife Investigations, edited by Linacre and Introduction to Veterinary and Comparative Forensic Medicine by Cooper and Cooper.

We hope that the various concepts, research and issues discussed in this edition are thought provoking and provide an insight into this significant global issue.

\section{References}

1. Wilson-Wilde L. Wildlife crime-a global problem. Forensic Sci Med Pathol. 2010;6:221-2.

2. Neme L. INTERPOL's Wildlife Crime Working Group Meeting. Forensic Sci Med Pathol. 2010;6:223-4.

3. CITES 2010. http://www.cites.org/eng/disc/what.shtml. Accessed 10 June 2010.

4. Alacs EA, Georges A, FitzSimmons NN, Robertson J. DNA Detective: A review of molecular approaches to wildlife forensics. Forensic Sci Med Pathol. 2010;6:180-94.

5. Tobe SS, Linacre A. DNA typing in wildlife crime: recent developments in species identification. Forensic Sci Med Pathol. 2010;6:195-206.

6. Spencer PD, Schmidt D, Hummel S. Identification of historical specimens and wildlife seizures originating from highly degraded sources of kangaroos. Forensic Sci Med Pathol. 2010;6:225-32.

7. McDowell D. Wildlife crime policy and the law. Canberra: Australian Government Publishing Service; 1997.

8. Ogden R. Forensic science, genetics and wildlife biology: getting the right mix for a wildlife DNA forensics lab. Forensic Sci Med Pathol. 2010;6:172-9.

9. Yates BC, Espinoza EO, Baker BW. Forensic species identification of elephant (Elephantidae) and giraffe (Giraffidae) tail hair using cross section analysis and light microscopy. Forensic Sci Med Pathol. 2010;6:165-71.

10. Byard RW, Tomo I, Kemper CM, Gibbs SE, Bossley M, Machado A, Hill M. Unusual causes of fatal upper aerodigestive tract obstruction in wild bottlenose dolphins (Turiops aduncus). Forensic Sci Med Pathol. 2010;6:207-10.

11. Byard RW, Machado A, Braun K, Solomon LB, Boardman W. Mechanisms of deaths in captive juvenile New Zealand fur seals (Arctocephalus forsteri). Forensic Sci Med Pathol. 2010;6: 217-20.

12. Carapetis E, Machado AJ, Byard RW. Lethal consequences of ingested foreign material in seabirds. Forensic Sci Med Pathol. 2010;6:242-3.

13. Johnson R. The use of DNA identification in prosecuting wildlifetraffickers in Australia. Do the penalties fit the crimes? Forensic Sci Med Pathol. 2010;6:211-6.

14. El-Sayed Y, Mohamed O, Ashry K, El-Rahman SA. Using species-specific repeat and PCR-RFLP in typing of DNA derived from blood of human and animal species. Forensic Sci Med Pathol. 2010;6:158-64.

15. Clarke M, Vandenberg N. Dog attack: the application of canine DNA profiling in forensic casework. Forensic Sci Med Pathol. 2010;6:151-7.

16. Wilson-Wilde L, Norman J, Robertson J, Sarre S, Georges A. Current issues in species identification for forensic science and the validity of using the cytochrome oxidase I (COI) gene. Forensic Sci Med Pathol. 2010;6:233-41. 